\title{
Determination of carbamazepine in pharmaceutical formulations
}

\author{
Lílian Grace da Silva Solon', Ana Isabel Maia de Oliveira1, Gerlane Coelho Bernardo Guerra ${ }^{1,2}$, \\ Luiz Alberto Lira Soares ${ }^{1,3}$, Aurigena Antunes de Araújo ${ }^{1,2, *}$
}

${ }^{1}$ Department of Pharmacy, Federal University of Rio Grande do Norte, ${ }^{2}$ Department of Biophysics and Pharmacology, Federal
University of Rio Grande do Norte, ${ }^{3}$ Department of Pharmaceutical Sciences, Federal University of Pernambuco.

\begin{abstract}
The aim of this study was to evaluate the quality of five different solid formulations of carbamazepine. The reference formulation was Tegretol® $200.00 \mathrm{mg}$ (Novartis) and the others were: generic formulation of carbamazepine $200.00 \mathrm{mg}$ (National Industry), similar formulation of carbamazepine $200.00 \mathrm{mg}$ (National Industry), and two formulations of carbamazepine $200.00 \mathrm{mg}$ acquired from two different compounding pharmacies. The latter consisted of capsules obtained in Natal, the capital city of the Brazilian State of Rio Grande do Norte. The quality of samples was evaluated through physical and physical-chemical tests, including: weight, diameter, thickness, content, dissolution, disintegration, hardness, friability and moisture. The results of friability analysis showed that all formulations met Brazilian and United States Pharmacopeia (USP) specifications. In spite of having a higher hardness compared to the reference, the generic formulation had a lower disintegration time. This could be associated to the presence of crospovidone in its formulation. Results of this study showed that all formulations had dissolutions which were in accordance with Brazilian Pharmacopoeia specifications, and quality control tests. An exception was found for the similar formulation, which had a hardness parameter that exceeded the USP standard. However, this difference was not significant given the similar formulation's satisfactory disintegration time.
\end{abstract}

Uniterms: Carbamazepine. Medicines/quality control. Generic medicines. Similar medicines. Medicines/ magistral formulation.

O objetivo desse trabalho foi avaliar a qualidade de cinco formulações de carbamazepina na dosagem de 200,00 mg: medicamento referência Tegretol ${ }^{\circledR}$ (Novartis), medicamento genérico (indústria nacional), medicamento similar (indústria nacional) e cápsulas do mesmo medicamento obtidas de duas farmácias de manipulação da cidade do Natal, RN. Os ensaios realizados foram: peso médio, diâmetro, espessura, teor, dissolução, desintegração, dureza, friabilidade e umidade. Foi observado que nenhuma das amostras analisadas apresentou friabilidade superior ao limite máximo determinado pela Farmacopéia Americana $(1,5 \%)$. O medicamento genérico, apesar de apresentar dureza superior em relação ao medicamento de referência, desintegrou em menor tempo, o que pode estar relacionado à crospovidona presente na formulação. As amostras analisadas atenderam às especificações da Farmacopéia Brasileira no que diz respeito à dissolução. Em geral, os resultados das amostras $\mathrm{A}, \mathrm{B}, \mathrm{C}, \mathrm{D}$ e $\mathrm{E}$ foram considerados satisfatórios uma vez que atenderam as especificações farmacopéicas. Embora a apresentação similar não tenha atendido ao padrão USP no que diz respeito à dureza, esse dado não se mostrou significativo, uma vez que o tempo de desintegração foi satisfatório.

Unitermos: Carbamazepina. Medicamentos/controle de qualidade. Medicamento genérico. Medicamentos similares. Medicamentos/formulação magistral.

\footnotetext{
*Correspondence: A. A. Araújo. Departamento de Biofísica e Farmacologia, Centro de Biociências, Universidade Federal do Rio Grande do Norte. Av. Senador Salgado Filho, S/N - Lagoa Nova, 59078-900 - Natal - RN, Brasil. E-mail: aurigena@ufrnet.br
} 


\section{INTRODUCTION}

The efficacy of carbamazepine efficacy was confirmed in the 1960s, when it was launched in the commercial market. It was used as an antiepileptic for the first time in the United States in 1974. Carbamazepine was initially prescribed for adult patients, and later indicated for use in children. Carbamazepine is considered one of the best anticonvulsivant, producing less psychological alterations and behavior effects (Castro et al., 2001). Carbamazepine is used in the treatment of trigeminal and glossopharyngeal nerve neuralgia, acting by reducing repetitive activation of the action potential (Goodman, Gilman, 2003).

This molecule shows unique pharmacokinetic properties giving it a low solubility in water (below $200.00 \mu \mathrm{g} / \mathrm{mL}$ ). After oral administration, it has a slow rate absorption which requires the use of a relatively large dose (Ambrogi et al., 2007).

Currently, several commercial presentations of carbamazepine are available in Brazil. Based on their source, they can be divided into reference, generic, similar and those produced in compounding pharmacies. According to Brazilian law 9.787, published in February $10^{\text {th }}$ of 1999 , reference medicines are those commercialized under registration in Brazil. Reference medicines contain the original drug, which was rigorously developed and investigated, and have been submitted to pre-clinical and clinical studies for evaluation of their safety and therapeutic efficacy (Yacubian, 2007).

Generic medicines have been in use in the United States and Europe since 1960. They can have a different formulation compared to the reference medicine, but must present the same dose, route of administration and presentation as the reference (Baracho, 2008). In addition, generics must have the same pharmaceutical equivalence and bioequivalence as the reference medicine. This must be attested by the regulatory agency of each country. In Brazil, this role is performed by the National Health Surveillance Agency (ANVISA) (Storpirtis et al., 2004). The bioequivalence guarantees that two presentations will have the same drug absorption rate and quantity and hence bioavailability (Yacubian, 2007).

The similar medicine is the form having the same drug, dose, pharmaceutical form, route of administration, dosage and indication as the reference medicine, but which has not necessarily been submitted to equivalence and bioequivalence studies.

The medicines acquired from compounding pharmacies are normally in capsule form. This pharmaceutical form permits a custom dosage of the drug, which reduces the cost compared to an industrialized medicine, and also facilitates acquisition of the medicine. The capsules also provide a means of obtaining a medicine that does not exist in the pharmaceutical market (Azevedo, Ribeiro, Araújo, 2008).

The aim of this study was to evaluate the physical and physical-chemical quality control of five formulations of carbamazepine, namely: a generic presentation, a similar presentation, and two presentations acquired from two different compounding pharmacies.

\section{MATERIALS AND METHODS}

\section{Materials}

A carbamazepine standard was acquired from Cristália Laboratory (Sao Paulo). The methanol used was purchased from Merck (Germany) and the sodium sulfate lauryl from Cromato Produtos Químicos Ltda. (São Paulo). Two formulations of carbamazepine were acquired from two different compounding pharmacies in Natal, Rio Grande do Norte, Brazil. Besides these two formulations, Tegretol ${ }^{\circledR} 200.00 \mathrm{mg}$ (Novartis) as the reference medicine, a generic formulation of carbamazepine $200.00 \mathrm{mg}$ (National Industry) and a similar formulation of carbamazepine $200.00 \mathrm{mg}$ (National Industry), were also used as shown in Table I.

TABLE I - Samples of reference, generic and similar tablets and magistral capsules of carbamazepine $200.00 \mathrm{mg}$.

\begin{tabular}{lc}
\hline Carbamazepine (200.00 mg) & Sample \\
\hline Reference tablets (Novartis) & $\mathrm{A}$ \\
Generic tablets (National Industry) & $\mathrm{B}$ \\
Similar tablets (National Industry) & $\mathrm{C}$ \\
Capsules (Compounding Pharmacy 1) & $\mathrm{D}$ \\
Capsules (Compounding Pharmacy 2) & $\mathrm{E}$ \\
\hline
\end{tabular}

\section{Instrumentation}

The following devices were used in the analysis: an analytical balance Ohaus ${ }^{\circledR}$ Adventurer model, digital caliper Mitutoyo ${ }^{\circledR}$, spectrophotometer Varian ${ }^{\circledR}$ Carry 50 Cone model, dissolutor Erweka ${ }^{\circledR}$ DT 80 model, disintegrator Digimatic Caliper Varian ${ }^{\circledR}$ VK 100 model, durometer Varian ${ }^{\circledR}$ VK 200 model, friabilometer Varian ${ }^{\circledR}$, infra-red balance Ohaus ${ }^{\circledR}$ MB 45 model, and an Ultrasonic Unique ${ }^{\circledR}$ Cleaner Ultrasound USC 1400 model.

\section{Methods}

The five formulations (A, B, C, D, and E) analyzed in this study were submitted to physical and physical-chemical tests. These tests were mean weight, diameter, thickness, content, dissolution, disintegration, hardness, friability and moisture.

Mean weight: twenty tablets/capsules of each formulation were individually weighed. The mean was obtained and the 
relative standard deviation (RSD) could not exceed 7.5\% (for tablets) and 10\% (for capsules) (USP).

Diameter and Thickness: a caliper was used to measure the diameter and thickness of ten tablets of A, B and C samples (USP).

Content: for this test, a stock solution was prepared by dissolving $10 \mathrm{mg}$ of carbamazepine in $100 \mathrm{~mL}$ of methanol and then a standard solution containing $10 \mu \mathrm{g} / \mathrm{mL}$ was obtained from the stock solution. A test solution of the five formulations (A, B, C, D and E) was made at the same concentration of 10.00 $\mu \mathrm{g} / \mathrm{mL}$ of carbamazepine. Absorptions of these solutions were determined at $285 \mathrm{~nm}$, using methanol as a blank. The sample analyzed could not contain less than $92 \%$ or more than $108 \%$ of carbamazepine (Farmacopéia Brasileira, 1977).

Dissolution: the dissolution medium used in this test was distilled water with $1 \%$ sodium sulfate lauryl (totaling $900 \mathrm{~mL}$ ). Six samples of each formulation were previously weighed and then placed in the dissolutor. All samples were submitted to 75 rpm on apparatus II (paddle) and $37 \pm 0.5^{\circ} \mathrm{C}$ temperature for 60 minutes. After finishing this step, aliquots were collected and analyzed at $285 \mathrm{~nm}$ (Farmacopéia Brasileira, 1977).

Disintegration: this test was performed according to USP's methodology. Six samples of each formulation had to disintegrate in less than 30 minutes (USP).

Hardness: this parameter measured the level of force necessary to the break the tablets. The test was performed on ten tablets of samples A, B and C. The results had to lie within a 4 to10 kilopound (Kp) range (USP).

Friability: twenty (A, B and C samples) previously weighed tablets were placed in a friabilometer with a pre-programmed speed for five minutes. After finishing this step, samples were reweighed and the difference in tablet weight calculated. The samples could not lose more than $1.5 \%$ in weight (USP).
Moisture: twenty tablets/capsules were sprayed with $1.5 \mathrm{~g}$ pounds and placed in an infra-red balance which measured moisture content. The samples could not lose more than $5 \%$ in weight (USP).

\section{RESULTS AND DISCUSSION}

Tablet weight is determined by the density of the formulation components and by its proportions. The USP establishes limits for mean weight of non-coated tablets that apply to tablets containing at least $50.00 \mathrm{mg}$ of active substance (drug) comprising more than $50 \%$ of weight. Tablets which have a mean weight of between 80.00 and $250.00 \mathrm{mg}$ may have a maximum weight variation of $7.5 \%$. The results of these tests are shown in Table II.

The dimension and form of tablets are determined by the type of compression tool used. Thus, this parameter varies with the compressive load applied and must be controlled to adhere to a maximum variation of $5 \%$.

The mechanical properties of tablets can be quantified by friability and hardness. The friability is directly related to the hardness and indicates resistance to abrasion, which can occur inside the end packaging or during transport or manipulation. This parameter is important in choosing the adequate excipients to prevent fast disintegration of the tablet and posterior dissolution of the drug before the desired time. The maximum loss of weight must not exceed $1.5 \%$ of tablet weight. The results of the friability test were $0.25 \%, 0.54 \%$ and $0.34 \%$ for samples A, B and C, respectively. These friability levels met USP specifications.

Hardness is an important parameter to estimate disintegration time, since resistant tablets do not disintegrate in the time required to satisfy the dissolution specifications. Tablets with lower hardness are unable to resist manipulation. The force needed to achieve tablet breakage is expressed in kilopounds $(\mathrm{Kp})$. The values found of between 4 and $10 \mathrm{Kp}$ are considered satisfactory for non-coated tables (oral administration). The similar presentation of carbamazepine (sample $\mathrm{C}$ ) had a hardness value greater than that determined by the USP (Table II). However, this result

TABLE II - Results of hardness, diameter, thickness, mean weight, disintegration, content and moisture tests of 200.00 mg carbamazepine tablets and capsules.

\begin{tabular}{|c|c|c|c|c|c|c|c|}
\hline Sample & $\begin{array}{c}\text { Hardness* } \\
(\mathrm{kP}) \pm(\mathrm{RSD})\end{array}$ & $\begin{array}{c}\text { Diameter* } \\
(\mathrm{mm}) \pm(\mathrm{RSD})\end{array}$ & $\begin{array}{l}\text { Thickness* } \\
(\mathrm{mm}) \pm(\mathrm{RSD})\end{array}$ & $\begin{array}{c}\text { Mean weight** } \\
(\mathrm{mg}) \pm(\mathrm{RSD})\end{array}$ & $\begin{array}{l}\text { Disintegration*** } \\
(\min ) \pm(\text { RSD })\end{array}$ & $\begin{array}{l}\text { Content**** } \\
(\%) \pm(\mathrm{RSD})\end{array}$ & $\begin{array}{c}\text { Humidity } \\
(\%)\end{array}$ \\
\hline A & $7.48 \pm 1.34$ & $9.02 \pm 0.65$ & $3.70 \pm 1.19$ & $295.52 \pm 4.25$ & $0 ’ 30 ” \pm 0.58$ & $96.57 \pm 2.37$ & 2.30 \\
\hline B & $8.39 \pm 0.87$ & $9.11 \pm 1.87$ & $4.89 \pm 2.17$ & $294.02 \pm 3.39$ & $0 ’ 25 " \pm 3.40$ & $98.34 \pm 1.05$ & 2.00 \\
\hline $\mathrm{C}$ & $17.86 \pm 2.89$ & $11.05 \pm 3.54$ & $5.28 \pm 3.89$ & $475.49 \pm 1.26$ & $2 ' 32 " \pm 4.33$ & $101.47 \pm 1.98$ & 3.67 \\
\hline $\mathrm{D}$ & - & - & - & $261.53 \pm 3.55$ & $4 ' 14 " \pm 2.35$ & $93.14 \pm 0.35$ & 3.08 \\
\hline $\mathrm{E}$ & - & - & - & $309.72 \pm 7.28$ & $4 ' 26^{\prime \prime} \pm 1.56$ & $94.14 \pm 1.13$ & 4.25 \\
\hline
\end{tabular}

$*_{\mathrm{n}}=10 ; * * \mathrm{n}=20 ; * * * \mathrm{n}=6, * * * * \mathrm{n}=3$ 
proved non-significant because the disintegration time within the 30-minute limit of this formulation was considered satisfactory.

As expected, the tablet with higher hardness presented a longer disintegration time. However, the generic presentation, in spite of having a greater hardness compared to the reference formulation, had a shorter disintegration time. This fact may be due to use of crospovidone in its formulation. This excipient is a super disintegrate, a substance that facilitates the disintegration process, even when used in small quantities (Prista, Alves, Morgado, 1995).

Absorption is a parameter which depends on both disintegration and dissolution parameters. Previously, only the disintegration was required as an indicator of a drug's release parameter. However, several studies showed that the turbulent agitation provided by apparatus II of the disintegrator contrasts with the smooth and normal agitation of the gastric content during the contractions of the stomach. In addition, these studies revealed that the disintegrated particles do not disperse in the organism, but remain aggregated. Therefore, the disintegration test is now used only to control the variations between each bulk size and should not be used as a bioavailability standard (Guyot- Hermann, 1992).

After oral administration, the solid forms can disintegrate or dissolve later upon interaction with the gastrointestinal fluid. Hence, the speed of dissolution controls the accumulation rate of the drug in the blood while its kinetics provide data about the bioavailability of a medicine as well as its therapeutic effects in vivo. For this reason, this test is gaining more importance in the pharmaceutical industry. It is a parameter used to evaluate the quality of a medicine (Menegola et al., 2007).

Table III shows that all presentations analyzed met the USP specifications regarding the dissolution test. Dissolution is an important test of quality control and acts as a useful tool to predict bioavailability. In some cases, it can substitute clinical studies determining bioequivalence. The term oral bioavailability is defined as the fraction of the administrated drug which reaches the bloodstream from the gastrointestinal tract (Bosso, 2008).

TABLE III - Results of dissolution test (S1 stage) of 200.00 mg. carbamazepine tablets and capsules

\begin{tabular}{lccc}
\hline Sample & $\begin{array}{c}\text { Maximum } \\
\text { dissolution }(\%)\end{array}$ & $\begin{array}{c}\text { Minimum } \\
\text { dissolution }(\%)\end{array}$ & $\begin{array}{c}\text { Mean* } \\
(\%) \pm(\mathrm{RSD})\end{array}$ \\
\hline A & 81.15 & 74.50 & $77.84 \pm 3.73$ \\
B & 96.87 & 92.63 & $94.25 \pm 1.70$ \\
C & 105.72 & 96.24 & $104.41 \pm 2.34$ \\
D & 96.10 & 90.74 & $94.10 \pm 2.14$ \\
E & 104.40 & 95.18 & $96.39 \pm 4.42$ \\
\hline
\end{tabular}

When an adequate dissolution method is chosen, the dissolution rate of the product can be correlated with the absorption rate of the drug in the organism. In general, a fast dissolution rate results in a fast rate of appearance of the drug in blood plasma. Thus, correlation between the dissolution rate and absorption rate of the drug can be established (Shargel, Ayu, Andrew, 1999).

As outlined above, the bioavailability of a drug is defined by its absorption speed and extension, and is important in determining whether the drug reaches its target site at an effective therapeutic concentration (Aulton, 2005). Bioavailability can be influenced by the route of administration, pharmaceutical form and formulation. The route of administration was not relevant in this study because all formulations analyzed used the same route. Variability in bioavailability exhibited by a drug incorporated in different pharmaceutical forms, or in different formulations of the same pharmaceutical form, can result in higher-than-desired plasmatic concentrations, thereby potentiating side effects, or in lower-than-required levels, precluding effective therapeutic action.

The effective surface area of a drug is an important factor that should be correlated with its speed of dissolution, particularly when dealing with low solubility molecules such as carbamazepine. When increased effective surface area is ensured, the disintegration of a tablet is an important factor for the drug's absorption. Should fast release, dissolution and consequent absorption be desired then tablets must disintegrate rapidly and completely in gastrointestinal fluids. The speed of this process is affected by the compression force applied during tablet production as well as by the concentration and type of drug and excipients (diluent, disintegrant, aggregating, lubricant and wetting agent).

A medicine which fulfils the requirements of the pharmacopeia in terms of dissolution, tends to indicate safe and satisfactory in vivo release.

Also concerning the contact surface, the bioavailability of a drug administrated in a gelatin capsule can be the same or even better than the bioavailability of a tablet containing the same drug. This can be the case because the gelatin capsule dissolves rapidly when in contact with the gastrointestinal fluids and liberates its contents, which disperses rapidly and efficiently.

The ANVISA do not currently have guidelines regulating quality control of similar medicines or drugs produced in compounding pharmacies. From this year, pharmaceutical equivalence tests will be required for these drugs, where determination in the laboratory shall verify whether they indeed possess the same characteristics as the reference drug. Bioavailability will be assessed only from 2014 (Rumel, Nishioka, Santos, 2006).

\section{CONCLUSION}

The quality control studies for the A, B, C, D and E solid formulations of carbamazepine $200.00 \mathrm{mg}$ were considered sa- 
tisfactory in that they met American and Brazilian Pharmacopeia specifications. An exception occurred with the similar presentation, which did not meet the USP specifications. However, this result proved irrelevant because the disintegration time of this formulation was considered satisfactory.

\section{ACKNOWLEDGEMENTS}

The authors are grateful for the support from the Núcleo de Pesquisa em Alimentos e Medicamentos (NUPLAM-UFRN), PROPESQ-UFRN and CNPq (477131/2007-7).

\section{REFERENCES}

AMBROGI, V.; PERIOLI, L.; MARMOTTINI, F.; ACCORSI, O.; PAGANO, C.; RICCI, M.; ROSSI, C. Role of mesoporous silicates on carbamazepine dissolution rate enhancement. Micropor. Mesopor. Mater, v.113, n.1-3, p.445-452, 2007.

AULTON, M. E. Delineamento de formas farmacêuticas. 2.ed. Porto Alegre: Artmed, 2005. 677 p.

AZEVEDO, R. C. P; RIBEIRO, G. P; ARAÚJJ, M. B. Desenvolvimento e validação do ensaio de dissolução para captopril em cápsulas magistrais por CLAE. Rev. Bras. Cienc. Farm, v.44, n.2, p.261-269, 2008.

BARACHO, N. C. V. Bioequivalence study of four different trademarks of enalapril maleate in spontaneously hypertensive rats. Acta Cir. Brás., v.23, n.2, p.173-178, 2008.

BOSSO, S. T.; ENZWEILER, J. Ensaios para determinar a (bio) disponibilidade de chumbo em solos contaminados: revisão. Quim. Nova, v.31, n.2, p.394-400, 2008.

BRASIL. Ministério da Saúde. Lei no 9.787 de 10 de fevereiro de 1999. Diário Oficial da União, Brasília, de 1999. Seção1. p.1.

CASTRO, A. P. B. M; REDMERSHI, M. G; PASTORINO, A. C; PAZ, J. A; FOMIN, A. B. F; JACOB, C. M. A. Secondary hypogammaglobilinemia after use of Carbamazepine: case report and review. Rev. Hosp.Clín. Fac. Med. S. Paulo, São Paulo, v.56, n.6, p.189-192, 2001.
FARMACOPÉIA BRASILEIRA. 3.ed. São Paulo: Andrei Editora, 1977. p.181.

GOODMAN, L. S; GILMAM, G. A. As bases farmacológicas da terapêutica. 11.ed. Rio de janeiro: Mc Graw Hill, 2007. $1821 \mathrm{p}$.

GUYOT-HERMANN, A.M. The disintegration and disintegrating agent. S.T.P.- Pharma Sci., v.2, n.6, p.445462, 1992.

MENEGOLA, J.; STEPPE, M.; SCHAPOVAL, E. E. S. Dissolution test for citalopram in tablets and comparison of in vitro dissolution profiles. Eur. J. Pharm. Biopharm., v.67, p.524-530, 2007.

PRISTA, L. N.; ALVES, A. C.; MORGADO, R. Tecnologia farmacêutica. 4.ed. Lisboa: Fundação Calouste Gulbenkian, 1996. 2257 p.

RUMEL, D; NISHIOKA, S. A; SANTOS, A. A. M. Intercambialidade de medicamentos: abordagem clínica e o ponto de vista do consumidor. Rev. Saúde Pública, v.40, n.5, p.921-927, 2006.

SHARGEL, L; AYU, ANDREW, B. C. Applied biopharmaceutics and pharmacokinetics. 4.ed. New York: McGraw Hill, 1999. $768 \mathrm{p}$.

STORPIRTIS, S.; MARCOLONGO, R.; GASPAROTTO, F.S.; VILANOVA, C.M. Equivalência farmacêutica no contexto da intercambialidade entre medicamentos genéricos e de referência: bases técnicas e científicas. Infarma, Brasília, v.16, n.9-10, p.51-56, 2004.

YACUBIAN, E. M. T. Medicamentos genéricos no tratamento das epilepsias: uma reflexão. J. Epilepsy Clin. Neurophysiol., v.13, n.3, p.127-130, 2007.

UNITED STATES PHARMACOPEA. 30.ed. NF 25. Rockville: USP Convention, 2007. 2751 p.

Received for publication on $04^{\text {th }}$ June 2009 Accepted for publication on $26^{\text {th }}$ January 2010 